\title{
A Method for the Preparation of Gastrin
}

\author{
By J. E. JORPES, O. JALLING AND V. MUTT \\ Chemistry Department II, Caroline Institute, and the Insulin Laboratory \\ of the Vitrum Company, Stockholm
}

(Received 16 January 1952)

Extraction of the hog pyloric mucosa with hot $0 \cdot 1 \mathrm{~N}$-hydrochloric acid, as applied in the earlier procedures for the preparation of gastrin (Edkins, 1906; Komarov, 1942a, b; Uvnäs, 1942; Uvnäs, Munch-Petersen \& Rönnow, 1944), yields an abundance of inert proteins. In a study of the properties of crude preparations of gastrin we made the observation that the active principle is very soluble in acid methanol. We found this solvent very satisfactory when used for extracting gastrin from hog pyloric mucosa.

Further, we found, during the course of the work, that the main bulk of the activity followed the proteins which flocculated on neutralizing the acid methanolic extract. Since only a few per cent of the total gastrin remained in solution, evaporation of the methanol was superfluous after neutralization. Furthermore, a purification was achieved through fractionating the first methanolic extract at different $\mathrm{pH}$ values. The precipitate obtained at pH 5 was as large as that obtained at pH 7, but the latter contained nine-tenths of the gastrin activity. When dissolved in water these fractions flocculated isoelectrically at the same $\mathrm{pH}$ values as in methanol. A second small fraction was separated at $\mathrm{pH} 5.5$ in methanol. For the sake of convenience, only the fraction flocculating at $\mathrm{pH} 7$ was used for further purification.

\section{METHODS}

\section{Preparation of the hog pyloric mucosa}

The stomach was removed not later than $1 \mathrm{hr}$. after slaughter, emptied of its contents, and everted. The pyloric part, making up a fourth of the stomach, was cut off, rinsed with cold water and immersed for $10 \mathrm{~min}$. in boiling water in order to destroy the enzymes. After cooling, the mucosa was carefully wiped clean of the slimy layer of mucus covering it and dissected free from the underlying muscular tissue. It made up about $20 \%$ of the pyloric part of the stomach. The dissected mucosa was then minced in a meat chopper, frozen and stored for several months at $-20^{\circ}$, a procedure which did not affect the yield of gastrin. About forty hogs yielded $1 \mathrm{~kg}$. of mucosa.

\section{Extraction of gastrin}

Deeply frozen mucosa (10 kg.) from about 400 animals was minced and suspended in $401.0 \cdot 1 \mathrm{~N} \cdot \mathrm{HCl}$ in $95 \%(\mathrm{v} / \mathrm{v})$ methanol (solution I: $5 \mathrm{ml} .2 \mathrm{~N}-\mathrm{HCl}+95 \mathrm{ml}$. water-free methanol). This and all subsequent operations were carried out at room temperature. After stirring for $2 \mathrm{hr}$. the suspension was strained through gauze and the cloudy liquor filtered through fluted paper. The clear filtrate was brought to $\mathrm{pH} 5$ with $\mathrm{N}-\mathrm{NaOH}$. (All $\mathrm{pH}$ measurements were made with the glass electrode.) A heavy precipitate formed at this stage. 5-10 g. of Hyflo Super-Cel were mixed with each litre of the suspension and the mixture filtered with suction. The filter cake contained about one-tenth of the total gastrin activity. The clear filtrate was brought to $\mathrm{pH} \mathrm{5.5}$, when a slight precipitate formed which was filtered off with the aid of Hyflo, and discarded. The filtrate was brought to pH 7 and the precipitate formed allowed to settle for half an hour. The supernatant was then decanted and discarded. The rather voluminous precipitate was either centrifuged down or filtered with the aid of Hyflo Super-Cel. The mother liquor was discarded and the precipitate dissolved in, or extracted with, about 2 l. of $0.1 \mathrm{~N}-\mathrm{HCl}$ in $99 \%(\nabla / v)$ methanol (solution II: $1 \mathrm{ml} .10 \mathrm{~N}-\mathrm{HCl}+99 \mathrm{ml}$. methanol). The dark-brown methanolic solution, which contained about three-fourths of the gastrin activity extracted from the mucosa with methanol can be stored for several weeks at $-20^{\circ}$ without any loss of activity.

\section{Preparation of purified gastrin}

Solution II (6 l., containing extract from about $30 \mathrm{~kg}$. of mucous membrane and 1200 animals) was precipitated by the addition of 241 . of ethyl ether. The precipitate was removed with suction and the filter cake washed with dry ethyl ether. The ether was allowed to evaporate and the filter cake, usually about $20 \mathrm{~g}$., half of which consisted of inorganic salts, was dissolved in $500-1000 \mathrm{ml}$. of distilled water. The $\mathrm{pH}$ of the solution, about $2 \cdot 5$, was brought to 6.8-7.4 with $0 \cdot 1 \mathrm{~N}-\mathrm{NaOH}$. The precipitate was collected by centrifugation, dissolved in about $200 \mathrm{ml}$. of $0.05 \mathrm{~N}-\mathrm{HCl}$ and reprecipitated at $\mathrm{pH} 7$. The precipitate was dissolved in $50 \mathrm{ml}$. or less of $0.05 \mathrm{~N}-\mathrm{HCl}, 1 \mathrm{l}$. of methanol was added and the gastrin reprecipitated by the addition of 11 . of ethyl ether to the clear solution. The precipitate, which contained most of the gastrin, was filtered with suction and dissolved in the smallest possible amount of distilled water (solution $A$ ).

The addition of 31 . more of ether to the mother liquor precipitated some more material, which also contained gastrin. The amount was about one-third of that in the first precipitate and the activity per unit wt. was likewise about one-third. Solution $A$ was dialysed for $12 \mathrm{hr}$. at $5^{\circ}$ under toluene against distilled water through which carbon dioxide was passed during the dialysis to prevent isoelectric precipitation of the gastrin. The inner fluid was freeze-dried. 
The dry powder weighed about $1.5 \mathrm{~g}$. The substance was readily soluble in distilled water and dilute acids. It was fairly stable in the dry state at room temperature, although some loss in activity did occur when it was stored for some months.

The substance is of protein nature and is free of histamine, as evidenced by blood-pressure experiments. When $1 \mathrm{mg}$. was injected intravenously into a cat, as described by Jalling \& Jorpes (1947), it induced in most animals a copious flow of a highly acid gastric juice. The amount secreted by different animals, however, showed great variations. We found values ranging from scarcely any secretion at all in a few animals to $32 \mathrm{ml} .0 \cdot 1 \mathrm{~N}-\mathrm{HCl}$ in a single instance. The mean response was about $10 \mathrm{ml} .0 \cdot 1 \mathrm{~N}-\mathrm{HCl} / \mathrm{mg}$. gastrin, corresponding to a potency of 10 units/mg., as defined by Jalling \& Jorpes. The most potent preparations previously reported are those of Komarov (1942b), having an activity of $0.4 \mathrm{unit} / \mathrm{mg}$., and those of Uvnäs (1942), usually with about $0.5 \mathrm{unit} / \mathrm{mg}$. (Kahlson, 1948), and in some instances claimed to vary between 1 and 10 units/mg. (Uvnäs, 1945).

\section{SUMMARY}

1. Gastrin has been extracted from boiled hog pyloric mucosa with $0.1 \mathrm{~N}$-hydrochloric acid in $95 \%$ methanol.

2. Impurities were removed on neutralizing the

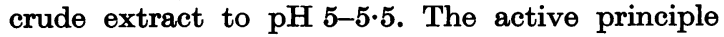
flocculated in the methanolic extract almost quantitatively at $\mathrm{pH} 7$.

3. Further purification was achieved through precipitation from water at $\mathrm{pH}$ 7. Inorganic salts were removed through dialysis.

4. $1 \mathrm{mg}$. given to an anaesthetized cat with vagi cut caused a gastric secretion containing about $10 \mathrm{ml}$. of $0.1 \mathrm{~N}$-hydrochloric acid, i.e. it contained about 10 secretory units (Jalling \& Jorpes, 1947).

This investigation was aided by grants from the Rockefeller Foundation and the Knut and Alice Wallenberg Foundation.

\title{
REFERENCES
}

Edkins, J. S. (1906). J. Physiol. 34, 183.

Jalling, O. \& Jorpes, J. E. (1947). Acta physiol. scand. 13, 231.

Kahlson, G. (1948). Brit. med. J. 2, 1091.

Komarov, S. A. (1942a). Rev. canad. Biol. 1, 191.
Komarov, S. A. (1942b). Rev. canad. Biol. 1, 377.

Uvnäs, B. (1942). Acta physiol. scand. 4, Suppl. 13.

Uvnäs, B. (1945). Acta physiol. scand. 9, 298.

Uvnås, B., Munch-Petersen, J. \& Rönnow, G. (1944). Acta physiol. scand. 7, 389.

\section{The Preparation of Secretin}

\author{
By J. E. JORPES AND V. MUTT \\ Chemistry Department II, Caroline Institute, and the Insulin Laboratory \\ of the Vitrum Company, Stockholm
}

(Received 16 January 1952)

Friedman \& Thomas (1950) described a method for the preparation of secretin on a large scale, and in a state of purity permitting its intravenous administration in man. Their method compares favourably with the older ones. Briefly it is as follows: the sodium chloride precipitate of an acid extract of hog intestine is extracted with methanol and the active material precipitated with acetone. Further purification is achieved by means of trichloroacetic acid. The final freeze-dried product has an activity of $100-130$ cat units/mg.

We found the method of Friedman \& Thomas very useful, although the yield of secretin was fairly low. Friedman \& Thomas noted that though vigorous stirring of the intestines during extraction increased the total yield of secretin, so much inert material was extracted at the same time that the secretin activity per unit weight of the final product was lower. We have confirmed this, but prefer to use the more efficient method of extraction, removing the inert protein at a later stage.

The principle introduced by these authors of extracting the secretin from the sodium chloride precipitate with methanol is very valuable. The same cannot, however, be said about the procedure of purification by means of trichloroacetic acid, which precipitates most of the inert proteins together with the active material. In our attempts to avoid using trichloroacetic acid we soon found that the bulk of the inert material was removed on neutralizing the methanolic extract. On adding sodium hydroxide in methanol to $\mathrm{pH} 7$ more than half of the protein matter present in the extract precipitated, while the secretin remained in solution.

The method described below gives, when properly adhered to, a secretin with an activity of from 600 to 900 cat units/mg. ash-free substance, and a yield of $1000-1600$ cat units $/ \mathrm{m}$. hog intestine. 